\title{
Analysis of the representation of cretaceous period in textbooks used in schools in the western region of the city of Ituiutaba, Minas Gerais, Brazil
}

\author{
Emerson J. F. ALVES ${ }^{1 *}$, Gerusa G. MOURA ${ }^{2}$ and Carlos R. dos A. CANDEIRO² \\ ${ }^{1}$ University State of Campinas, Institute of Geosciences, R. John Pandiá Calógeras, 51, \\ University City Campinas, SP - Brazil. \\ ${ }^{2}$ University Federal of Uberlândia, Faculty of Integrated Pontal, Twenty Street, 1600, \\ Tupa, 38304402- Ituiutaba, MG - Brazil.
}

Accepted 8 July, 2013

\begin{abstract}
This article aims to analyze the geography textbooks, which are being used in the public schools of the city of Ituiutaba, Depth of Minas Gerais, Brazil. The research also seeks to address the ways and methods being employed by the teachers of these schools for studies that include the teaching of Geology and Geosciences. In this study, survey methods that enabled mappings of the public schools of the city of Ituiutaba, cataloging and analysis of the objective results of the final results were used. The final results of this research show that feasibility study can contribute to the teaching-learning in schools as well as support future studies on assisting the education of geography.
\end{abstract}

Key words: Geography, teaching, textbook, education.

\section{INTRODUCTION}

The teaching of Geosciences carries with it a field of possibilities and helps in the development of the outlook as a totality, thereby bringing about comprehension of the procedural dynamics of natural phenomena which interact among themselves and living beings, and includes the natural procedures addressed in Physical Geography, Chemistry and Biology. These possibilities include a range of contents aimed at the Geosciences thereby making this an inter-disciplinary science which prepares analytical, critical and propositional citizens.

Throughout the history of Brazilian education, textbook has been an existing element involving several state policies. The quality of textbook presents a constant concern among various authors like Libâneo (1985) and Vasconcelo et al. (2003).

Geoscience is a study of the various processes occurring in the Earth's surface. Geosciences are the sciences that deal with the conditions of development, production and use of concepts, theories and models and scientific institutions as well as research methods and techniques used in teaching and research. This science has established itself as an in-depth research on topics and content designed for natural processes (Alves et al., 2012).

According to Frodeman (1995), "Historically the principal large areas of knowledge are: Physics, Geography, Mathematics, Chemistry and Biology, so as to construct quantitative knowledge of the principal areas and spheres of learning".

Geosciences deal with the conditions of production, incorporation and use of concepts, theories and scientific models, as well as methods and techniques of investigation employed in the teaching and research of Geosciences. These sciences are consolidated as a line 
of research based on themes and contents which consider natural processes. The Geosciences (Science of the Earth) is a wide ranging term applied to the sciences related to the planet Earth (Huertas, 2007; Peloggia, 1995).

The changes in society have offered us constant invitations to reflect on the process of teaching and learning, especially on the methods of teaching, the contents chosen, the instruments utilized, among others. The area of public institutions of elementary and grammar school teaching is a privileged place in which learning can be developed.

The Lei de Guidelines e Bases and Education Nacional (Brazil, 1996), (Law on Guidelines and Bases for National Education) together with the orientation offered by the National Curriculum Parameters (Brazil, 1997), have offered more flexibility in the curricula of elementary and grammar school teaching. This flexibility has allowed teachers and teaching institutions more autonomy in the manner in which they approach Geography in their classrooms, thereby allowing teaching that is more dynamic, coherent, integrated and stimulating.

This study is aimed at demonstrating the educational strategies which can be used in the teaching of the Geosciences; therefore we made a short introduction on the analysis carried out in the elementary and grammar level public schools in the western region of Ituiutaba, Minas Gerais. We also made a survey about the Geography textbooks from the point of view of the Geosciences in the Cretaceous period and the possibilities of improvement in teaching of this science through textbooks.

According to Sposito (2006), the textbooks should be understood as an element intermediation in the process of teaching and learning as a commercial product which contains knowledge for the formation of the student, as a product which must have quality from the point of view of formulation and durability, and as an object to be purchased by the Federal Government for distribution to schools throughout Brazil. It is with this conceptual characterization that the textbook brings with it the determinations of a very important public policy for Brazilian basic education because this incorporates, both directly as well as indirectly the tension between the various subjects involved in it.

It is to be noted that the textbook, the student and the Geography teacher are all important subjects in the teaching and learning process in schools. For this reason it is necessary that the teacher utilize contents from innumerous disciplines necessary in the teaching of Geosciences.

According to Paschoale (1989), innumerous sub-areas of the Geosciences are known within the academic community and society in general and they can be distinguished as, for example, (1) Geology/Physical Geography - which is studies the constitution and history of the development of the rocky parts of the crust (lithosphere) and the earth's surface, and has a correlative disciplines Geology, Sedimentology, Physical Geology, Geomorphology, Geoprocessing, Cartography; (2) Sciences of the soil - which study the more exterior layers of the earth's crust which undergoes processes which lead to the formation of soil (or Pedosphere); Sciences of the Atmosphere - which study the gaseous zones of the Earth (atmosphere) situated between the surface and the Exosphere which includes as subdisciplines Meteorology and Climatology.

The city of Ituiutaba has today, 34 municipal and state public institutions. However these institutions still lack a survey concerning the conditions of teaching and learning related to the Geosciences which are dealt with in Geography textbooks used in elementary and grammar schools; therefore it is necessary to carry out a complete diagnosis of textbooks as well as those dealing with the Cretaceous period.

Differently from other sciences, Geology is developed starting from descriptions of the natural environment, characterized as an inductive science, or better, it is developed from observations and records of local and global phenomena which come from models and formulate hypothesis. In the teaching of Geosciences the transmission of knowledge comes from the objective description of that which is being studied, that is to say, the approach is widened, but these become pragmatic due to lack of a more solid theoretical-methodological and, above all, specific base; that is only aimed at the use of concepts as described by Compiani (2005). Students must learn the fundamental concepts, its explanatory value and its function within the architecture of the Science of Geology; there is therefore a "Geological Thinking". This escapes from the binary logic which we are accustomed to and which is re-enforced by the teaching of traditional science.

From this point of view, the current considerations on the process of teaching the Geosciences point at teaching based on the construction of concepts by the students themselves, mediated by the teacher. In this process of forming concepts, the teacher, as a mediator, must offer the expression, communication of diversity of symbols, meanings, values, attitudes sentiments, expectations, beliefs and knowledge which are presents in a certain group of students which lives in a specific context, striving at understanding how each group specifically elaborates this diversity and promote dialogue between the these diverse forms of this elaboration, seeking a dialogue of these forms with the scientific (Cavalcanti, 2005).

The comprehension of Cretaceous period makes students understand the various processes that occur in the constitution of the Earth. The Cretaceous period is the last period of the Mesozoic era between 145 and 65 million years ago. The fauna of the Cretaceous period marked the apogee of Dinosaurs.

These large reptiles dominated the world during this 
period and lived in the seas and on land. From the book Geography: Constructing Consciousness" and shows the probable reconstruction of landscape before the extinction of Dinosaurs. In order to know this period more profoundly the student must have technical and scientific concepts besides having profound notions of both Geosciences and Geology.

The importance of teaching about the Cretaceous period lays in the fact of being able to give the students geological notions thereby informing them of the processes of the formation of the Planet Earth, which is essential in facilitating their learning besides helping them to understand the Cretaceous period and the modifying processes of the earth structure. In this manner, students will start having practical reasoning regarding the earth formations, and stop being passive in the process of teaching-learning, thereby obtaining qualified learning.

\section{MATERIALS AND METHODS}

Since we are dealing with scientific research, the first step of this study was based on the bibliographic survey and reading about the teaching of Geosciences. The second step was the identification of teaching institutions in the western region of Ituiutaba. The third step was the analysis of the quality of the teaching and learning process in the schools which were surveyed. In the fourth step, the contents of Geosciences (sensu Physical Geography) offered in the textbooks used in the selected schools. The finally, the last step was the identification of Geography textbooks which deal with the Cretaceous period.

\section{Analysis of textbooks in relation to cretaceous}

The Geosciences is the science that records the existence of organisms on the Earth's past alive. This evidence can provide information on the fossils. These are the remains or traces of bodily activity of living beings. The understanding this sciences is a key requirement for the discussion of more specific topics focused on the evolution and origin of life processes.

In the textbooks examined, the concept of Geosciences appears more than once, however, it appears superficially specification. The importance of the content and settings studied by science impoverishment Geosciences explains the definitions and concepts of science paleontological making it easier to understand the importance of natural science.

As geography textbooks, there was which are suitable as Geosciences. From the analysis of textbooks, the concepts were used in the classroom. The textbook includes text that the importance of Geosciences in science is not revealed, but it is the ideas about Earth process and knowledge about training operation and maintenance of the fossils.

However, it is important to emphasize, however, no mention of Geosciences through descriptions/ information that presents the main physical biological, geological changes on Earth. Thus, there is mentioned geological time decoupling Geosciences of natural processes, which in turn, with the organization in understanding and perception of time involved in the evolution of living beings.

The knowledge explained in the form of educational content is proposed superficially, since textbooks are identified in the formation of the first living beings, cooling planet earth, the formation of the oceans, and the appearance of the first amphibians, emerging and extinction of Dinosaurs, the occurrence of the first mammals. The
Geosciences processes are related to the types of studies of science.

The textbooks consider the study of the Cretaceous as evidence of evolution processes, the key to understanding the origins of life on Earth, allowing the reconstruction of geological, biological, chemical and physical processes.

\section{RESULTS, DISCUSSION AND CONCLUSION}

Concerning Geography textbooks, it was found that they are adequate as far as Geosciences in the elementary and grammar school levels are concerned. Starting from analysis of textbooks, concepts of the Cretaceous period were used in the classroom. Specific ideas dealing with Geosciences are mentioned in the "Geografia: Construindo Consciences" textbook where the importance of Geosciences in the scientific field is revealed; it also represents ideas about the process of the Earth's formation and knowledge concerning the exploration and conservation of fossils.

Furthermore, the information is on pre-hstoric periods which come after the transformations on the Earth System. This knowledge is related to/ and explained in the form of didactic contents with superficial proposals. This is because it is a description of the followings: the formation of the first living beings; the cooling of the Planet Earth; the formation of oceans; the appearance of the first amphibians; the emerging and extinction of Dinosaurs; the occurrence of the first mammals; the development of agriculture, among others.

It is important to point out that the contents presented in the books do not construct teaching and learning from a scientific point of view, because these contents are presented in a superficial form and present basic subjects related to the Cretaceous period and the processes of the formation of the Planet Earth.

The book "Geography: Constructing Consciousness" aims its teaching at the Cretaceous period and differs from the other books which were analyzed in that it principally deals with questions related to the structure and processes contained in the formation of Earth, with improvement of knowledge aimed at Geology with explanations of the processes which caused the formation of the landscape and procedural descriptions which strengthen the teaching and learning of Geographic Sciences.

This book is devoted to the sixth year of elementary teaching. The knowledge presented in this book demonstrates appropriate didactics for the age level for which it is used at the State School Doctor Alexandre. Other books which were analyzed (listed below) for the grammar school level approach more complex subjects such as: Geomorphology, Climatology, Cartography, Environmental Analysis, among others, however they do not touch anything about the Cretaceous period. These textbooks are: Garcia, Helio C; Garavello, Tito M. Geography "The Space America Oceans and Polar Regions" (2011); Moderna "Project Arariba" (2011); Garavello, Tito M; Garcia, Helio Carlos "The Space 
formation Geography, Europe, Asia and Africa" (2011). The Geography textbook must be understood as an element of intermediation in the educational process, product which contains knowledge necessary for the formation of the student.

The analysis of the annual planning of Geography teachers in the above mentioned institutions show that at no moment are there indications relating to knowledge of the Cretaceous period, only analyzing questions concerned with natural transformations and their subsequent changes what actually can be noted in the Geography teachers planning is that it is aimed at the study of structural and procedural Geology, revealing questions concerning the movement of tectonic plates, processes of folds and faults, besides questions related to reliefs, without identifying Pre-Historic scientific processes related to the Cretaceous period.

The aforementioned themes are represented in the planning of Geography in elementary and middle school teaching. From the point of view of learning the, didactics followed in the methodology of superficial teaching does not attend to the scientific explanations with explanations and descriptions of Pre-Historical periods related to the past of the Planet Earth. These contents presented in the annual Geography planning not permit methodological scientific knowledge. But we cannot only lean on knowledge geological found in Geography textbooks. It is necessary that the teacher utilize knowledge of pre-past periods of the Earth system.

In the analysis of textbooks found in the schools surveyed in the western region of Ituiutaba it has be observed that the teaching of Geosciences in public schools is integrated quality teaching principally in the understanding that students have of Geography. These changes are mainly due to the improvement of educational professionals, Geography textbooks and students since it is important to note the commitment with teaching and learning which permits analytical and critical thinking.

To appreciate the contents of the book "Geography: Constructing Consciousness" we must consider questions relative to sixth grade teaching. It is important to point out that this book formalizes subjects concerning geological questions and should be considered as a source of knowledge which facilitates comprehension geological processes and structures.

\section{FINAL REMARKS}

From this analysis, we consider that the analyzed textbooks have broad approach of the basic themes of the Cretaceous period. However, the approach is more accurate and complete collection in Geography:

"Constructing Consciousness", which accurately describes the theme.

The content on the Cretaceous are covered as part of the references in geosciences. However, the definition does not appear in this science collection, and receives little attention from the authors. The conceptual confusions and errors are present in the books, regardless of the subject studied.

In this sense, there are not enough updates to incurporate new information from the scientific community. Based on this analysis, it is recommended to authors of books for Geography for the set of concepts of elementary school, to use current and accurate concepts of Geosciences. Therefore, we emphasize also the need to greater coordination between the concepts of Geosciences in relation to the Cretaceous, and that an interface with Paleontology, Geography, Geology and Geomorphology.

Importantly, the content presented in textbooks is adding to the teaching and learning of scientific knowledge, the contents are presented in a superficial, but offers basic issues related to the Cretaceous period. In this condition, the teaching observed concerning the Cretaceous mainly deals with issues related to the structure and processes contained in the formation of the earth.

Textbooks should be surveyed regarded as an important intermediary in formation process as a product containing the knowledge required for the student's education. The knowledge of Geosciences is related to natural resources changes and its subsequent amendments, revealing issues related to natural processes studied by Geosciences, as well as issues related to the periods of transforming the earth.

These changes are due mainly to the improvement of education professionals, students and geography books, since it is important to emphasize the commitment to teaching and learning that allows the critical and analytical thinking. Importantly, this textbook formalize questions of geology, should be considered as a source of knowledge that facilitates the processes of understanding and geological structures.

Based on research done previously, that marked the knowledge of Geosciences in textbooks, it is recommended that authors of textbooks and collections of Geography for Elementary Education in Conceptual Use to use current and accurate classifications of Geosciences.

We also emphasize the need for greater coordination between the paleontological and geological concepts. Thus it should be clear and adequately explain the importance of paleontology to understand the evolution of the processes that occur on Earth. Thus, researchers such as Montardo (2006), Silva and Compiani (2006), Lima et al. (2007) and Malafaia and Lima (2008), assists in research in this topic.

Are suggested to seek more precise information on this subject, for example, work in the classroom. However, we suggest expanding and improving comprehensive explanations topics related to the natural sciences, which are essential to the understanding of natural processes, 
especially when related to natural processes, such as the Cretaceous period.

\section{ACKNOWLEDGEMENTS}

The authors wish to thank Professor Doctor Gerusa Goncalves Moura who aided us in this scientific voyage, and especially Professor Doctor Carlos Roberto A. Candeiro who helped us in all the practical and theoretical aspect of this work as well as in the bibliography. Finally, we are grateful to all our colleagues especially those of the Geology Laboratory, for their assitance given to us in this scientific research.

\section{REFERENCES}

Alves EJF, Moura GG, Candeiro CRA (2012). A importância Extensionista of Projeto Ciências da Terra: Praticando e Compreendendo as Geociências na Região do Pontal do Triângulo Mineiro. Revista Caminhos de Geografia 13:231-239.

Brazil (1996). Ministério da Educação- MEC. Leis de Diretrizes e Bases - LDB. Brasília.

Brazil (1997). MEC-Ministério da Educação. Parâmetros Curriculares Nacionais de Geografia - PCN'S. Brasília.

Cavalcanti LS (2005). Cotidiano, Mediação Pedagógica e Formação de Conceitos: Uma Contribuição de Vygotsky ao Ensino de Geografia. Campinas 25:66-190.

Compiani M (2005). Geologia/Geociências no Ensino Fundamental e a Formação de Professores. Geol. USP. São Paulo Vol. 3.

Compiani M (2007). O Lugar e as escalas e suas dimensões horizontal e vertical nos trabalhos práticos: implicações para o ensino de ciências e educação ambiental. São Paulo 3(13):150-152.

Frodeman R (1995). Geological reasoning: Geology as an interpretive and historical science. Geol. Soc. Am. Bull. 8(107):960-968.

Garcia HC, Garavello TM (2011). The Espaco America Oceans and Polar Regions. Ed. Scipione. São Paulo.
Garavello TM; Garcia HC (2011). The space formation Geo, Europe, Asia and Africa. Ed. Scipione. São Paulo.

Huertas DM (2007). Além do aspecto puramente acadêmico: o trabalho de campo como uma verdadeira experiência de vida. GEOUSP Espaço e Tempo, São Paulo 21:149-156.

Libâneo JC (1985). Democratização da escola pública: a pedagogia crítico-social dos conteúdos. 2. Ed. São Paulo: Loyola.

Lima MG, Lopes CS (2007). Geografia e ensino, conhecimento científico e sociedade. Maringá: Massoni.

Malafaia G, Rodrigues LAS (2008). Uma Reflexão Sobre O Ensino De Ciências no Nível Fundamental da Educação. Ciência e Ensino 2:2.

Moderna (2011). Geography Projet Arariba. São Paulo. Ed: Moderna p.216.

Montardo DK (2006). Geological Processes and Materials studies Supporting Environmental Knowledge's: College and School Interactions. Ijuí, RS, BRASIL.

Paschoale C (1989). Geologia como semiótica da natureza. São Paulo. Dissertação (Mestrado) - Pontifícia Universidade Católica de São Paulo. São Paulo.

Peloggia AUG (1995). A dialética da Geologia Temas e Geologia inspirados na obra de Friedrich Engels e sua aplicações. Revista Brasileira de Geociências, São Paulo 25:107-110.

Sposito MEB (2006). Livros Didáticos e História e Geografia: Avaliação e Pesquisa. São Paulo. Ed. Cultural acadêmica.

Silva FKM, Compiani M (2006). Las imágens geológicas y geociências en libros didáticos de ciencias. Campinas. Ed.2, p. 207-217. Vasconcelo C, Praia JF, Almeida LS (2003). Theory of learning and the teaching-learning of sciences-from instruction to apprenticeship. Educ. Sch. Psychol. (7)1. 